\author{
Jurnal Segara \\ http://ejournal-balitbang.kkp.go.id/index.php/segara \\ ISSN : 1907-0659 \\ e-ISSN : 2461-1166 \\ Nomor Akreditasi: 766/AU3/P2MI-LIPI/10/2016
}

\title{
LAND USE CHANGES ANALYSIS IN JAKARTA BAY COASTAL AREA BETWEEN 1998, 2008 AND 2018
}

\author{
Anwar Rizal'1), \& Fikri Haykal2) \\ ${ }^{1)}$ Marine Research Center, \\ Agency for Marine and Fisheries Research and Human Resources Agency, MMAF \\ ${ }^{2)}$ Universitas Negeri Padang \\ Received: 17 May 2016; Revised: 19 May 2016; Accepted: 21 Desember 2021
}

\begin{abstract}
As the national capital and one of the largest cities in the world, environmental conditions and land use in Jakarta have changed a lot in the last twenty years. Economic growth and high population growth in Jakarta have resulted in massive development of infrastructure and residential areas in Jakarta. Economic growth and an increase in population are become problems, especially with the decreasing of green areas due to the development process carried out without paying attention to the surrounding environment. Environmental problems such as water pollution, land subsidence, coastal erosion and flooding often occur in the Jakarta area, especially in the coastal areas of North Jakarta. Here, we used Landsat image data to compare land-use conditions in the coastal areas of Jakarta in the period of 1998- 2018. The research showed that the area of mangrove has increased by 79 hectares during 1998 -2018 period. likewise, the built-up areas and open land increased by 292 hectares and 887 hectares respectively. Meanwhile, the area of vegetation, water bodies, and fishpond has decreased by 393 hectares, 797 hectares and 309 hectares respectively. Development and reclamation have changed land-use in the Northern area of Jakarta. However, it is also necessary to pay attention to the impact of development on environmental and social conditions in the North Jakarta area.
\end{abstract}

Keywords: Environmental problems, Land-use, North Jakarta. 


\section{INTRODUCTION}

Most major cities in Indonesia face the threat of flooding, erosion, land subsidence and other environmental problems. These problems have seriously affected coastal communities, coastal ecosystems, infrastructure and social and economic conditions. Jakarta is the capital city of Indonesia, this area is the largest and most populous city compared to other cities in Indonesia, covering of $662 \mathrm{~km}^{2}$ land areas and of 6,977 $\mathrm{km}^{2}$ sea areas (BPS, 2017). Jakarta is bordered in the South and East by the province of West Java, in the West by the province of Banten, and in the North by the Java Sea. The total population of Jakarta in 2015 is around 10 million people, where during the day there is an additional population of around 2.5 million people who are commutes and lived around the Jakarta area (such as Tangerang, Bekasi, Depok, and Bogor) (Firman et al., 2011). By 2030, it is estimated that the population of Jakarta will increase to around 30 million (Takagi et al., 2016).

Jakarta was Initially a trading center and port of the Pajajaran Kingdom (around the $5^{\text {th }}$ century) and was known as Sunda Kelapa (BPS, 2017). This port was then developed into a trading center of European nations who do the spice trade in Asia. The Dutch trading company for Asia and India (VOC) then established a trading office in Sunda Kelapa and changed the name of the area to Batavia. Several Dutch heritage buildings are still standing well in Jakarta and become tourist destination areas both for local and foreign tourists. After Indonesia's independence in 1945 Batavia was renamed by Jakarta and designated as the capital city of the Republic of Indonesia, the development that took place in Jakarta became very rapid. Data from the Central Statistics Agency shows that the population in Jakarta has increased sharply in the past 40 years, from 4.8 million in 1975 to 10 million in 2015.(BPS, 2017).

Geographically, Jakarta is located in the Northwest of the island of Java and includes lowlands with an average height of 7 meters above sea level. The Jakarta area is crossed by several large rivers originating from the mountains in the South which drains into Jakarta Bay in the North of Jakarta. Jakarta Bay covers an area of $514 \mathrm{~km}^{2}$ with an average depth about 15 meters.

Development that occurs in an area tends to be accompanied by the growing process of the area. Development process and growing process in the areas is a process of land conversion to meet community needs for facilities and infrastructure to support their home living. The impact of development activities will affect the quality of the environment, therefore it must always be taken into account, both positive and negative impacts which must always be controlledlssues related to the environment, among others, are related to the decline in the quality of the urban environment. Therefore, it is expected that the government can control the progress of the development process and also cooperate directly with the community as directly related parties and become targets or objects in development in order to create a good and sustainable environment. (Pranoto, 2009).

Jakarta Bay is one of the strategic areas in Indonesia, which reflects the capital city of Indonesia. It includesthe Coastal Areas of Tangerang, Jakarta and Bekasi, and is covering three provinces (i.e. Banten, DKI Jakarta and West Java). The Jakarta Bay is classified as a "Special Area Development", which embodies a holistic conception of development, regarding the conservation, preservation and development, as follows: (1). Conservation: maintaining greening areas that are still possible, while reducing the level of pollution, especially the coastal areas of Jakarta Bay; (2). Preservation: enhancing environments that have historical values for the benefit of educational and recreational aspects; (3). Development: providing space for development activities that have special value in the context of improving community welfare and national interests, without adding a new pollution burden to the surrounding environment; (4). Developing recreational facilities for the public interest ( $\mathrm{NCICD}$ Consortium, 2015).

The latest information of land cover and land use in the form of maps can be obtained through remote sensing techniques. Remote sensing has long been an important and effective means of monitoring land cover with its ability to provide information on the spatial diversity on the earth's surface with a fast, comprehensive, accurate, and easy. (Hansen et al., 2000; Liu et al., 2003; Thenkabail et al., 2009; Gong et al., 2013). Sources of remote sensing data are an important factor in the success of land cover classification (Jia et al., 2014). Landsat satellite data is usually used in remote sensing for land cover classification (Gumma et al., 2011; Gong et al., 2013), thus the latest land cover maps can be obtained easily. Based on the updating of data, information obtained through remote sensing is considered to be better than information from related government agencies. Through remote sensing, we can get the latest data record to do land cover analysis.

Remote sensing can be defined as a technology to identify an object on the earth's surface without direct contact with that object. Currently satellite-based remote sensing technology is becoming very popular and is used for various purposes, one of which is to identify potential resources in coastal areas and oceans. This technology has several advantages, such 
as: the price is relatively cheap and easy to obtain, the existence of a temporal resolution (repeating) so that it can be used for monitoring purposes, its wide coverage and is able to reach remote areas, the form of data is digital so that it can be used for various purposes. and displayed for its intended purpose.

The use of remote sensing is very useful for obtaining the latest information with relatively less cost and time to do it. Therefore, it is important to calculate the area of mangroves in the Coastal Areas of North Jakarta by utilizing remote sensing data.

The coast of Jakarta has undergone many changes, especially with the massive development along the coast for business and residential areas. The study aims to answer the research question: "How much land use change in coastal Jakarta during the period 1998 to 2018?" During that time, Jakarta experienced a fairly rapid development in term of infrastructure development and population living in Jakarta, and to answer that question we explore the land use across Jakarta coastline using Landsat images and exploring anthropogenic factors that affect the ecosystem and the implication on environment and society in Jakarta. To achieve these objectives, the writer uses high-resolution Landsat images to investigate the changes of land-use in Jakarta coastline during the period 1998 to 2018.

\section{METHODOLOGY}

\section{Study Location}

The study focus on the areas of mangrove forest in Jakarta bay including Muara Angke and Muara Gembong. Mangrove forest in Angke is located near the river mouth with more than 40 mangrove species lived in this area. Some of the mangrove species are Avicennia alba, Avicennia marina, Avicennia officinalis, Excoecaria aqalocha, Rhizophora apiculate, Rhizophora mucronate, Sonneratia cnseolnris etc. Previous research conducted in 2013 found about 47 types of mangrove species from 24 families living in the area of Angke Kapuk (Kusmana et al., 2013).

Mangrove forest in Muara Gembong area is located in the East part of Jakarta Bay and is part of
Bekasi, West Java. Mangrove forest in Muara Gembong is managed by the Indonesian forest company (Perum Perhutani). Data from local authority showed that mangrove area in Muara Gembong is declining continuously (around 1,000 hectares per year). Currently, the remaining mangrove forest in Muara Gembong is around 16 percent or 1,400 hectares. Aquaculture activities in Muara Gembong coastal areas caused damages to mangrove forests. Moreover, more than 7,000 hectares mangrove forest are cleared for the opening of new brackish ponds (Pribadi, et al, 2016).

\section{Data Collection}

The data used in this study include the Landsat Image and Administrative Map of the Jakarta area, the Landsat imagery used in this study was downloaded from the official website United States Geological Survey (USGS) (http://earthexplorer.usgs.gov/, accessed in June 2018).

Landsat TM (Thematic Mapper) data is widely applied in various mapping activities, including land cover mapping, land use mapping, land mapping, geological mapping, sea surface temperature mapping and others. For land cover and land use mapping, Landsat TM data is preferred than multispectral SPOT data because there is an intermediate infrared band (Thoha, A. S., 2008). Landsat TM is the only nonmeteorological satellite that has an infrared thermal band. Thermal data is needed for the study of energy processes on the earth's surface, such as the variability of plant temperature in irrigated areas (Thoha, 2008). Some of the advantages using Landsat imagery are the availability of time series image data and the resolution (spatial, temporal, radiometric) is quite good (Sugiarto, 2013).

While the process of analysis and interpretation of Landsat imagery aimed to see the changes in land cover during the periods in Jakarta in this study is attached in the flow diagram (Figure 1).

\section{Data Processing}

Data processing is carried out in several stages, such as combining images, selecting the best band combination, visual image interpretation and creating

Table 1.

Field observation results

\begin{tabular}{ll}
\hline Data & Function \\
\hline Landsat Image 5 TM Path 122 Row 64 & the primary data (subject to be processed) \\
$\begin{array}{l}\text { Recorded 1998 dan 2008 } \\
\text { Landsat Image 8 OLI Path 122 Row 64 }\end{array}$ & Primary the data (subject to be processed) \\
$\begin{array}{l}\text { Recorded 2018. } \\
\text { Administration Map Sub District in }\end{array}$ & Secondary data (to limit the scope of the study \\
North Jakarta & \\
\hline
\end{tabular}




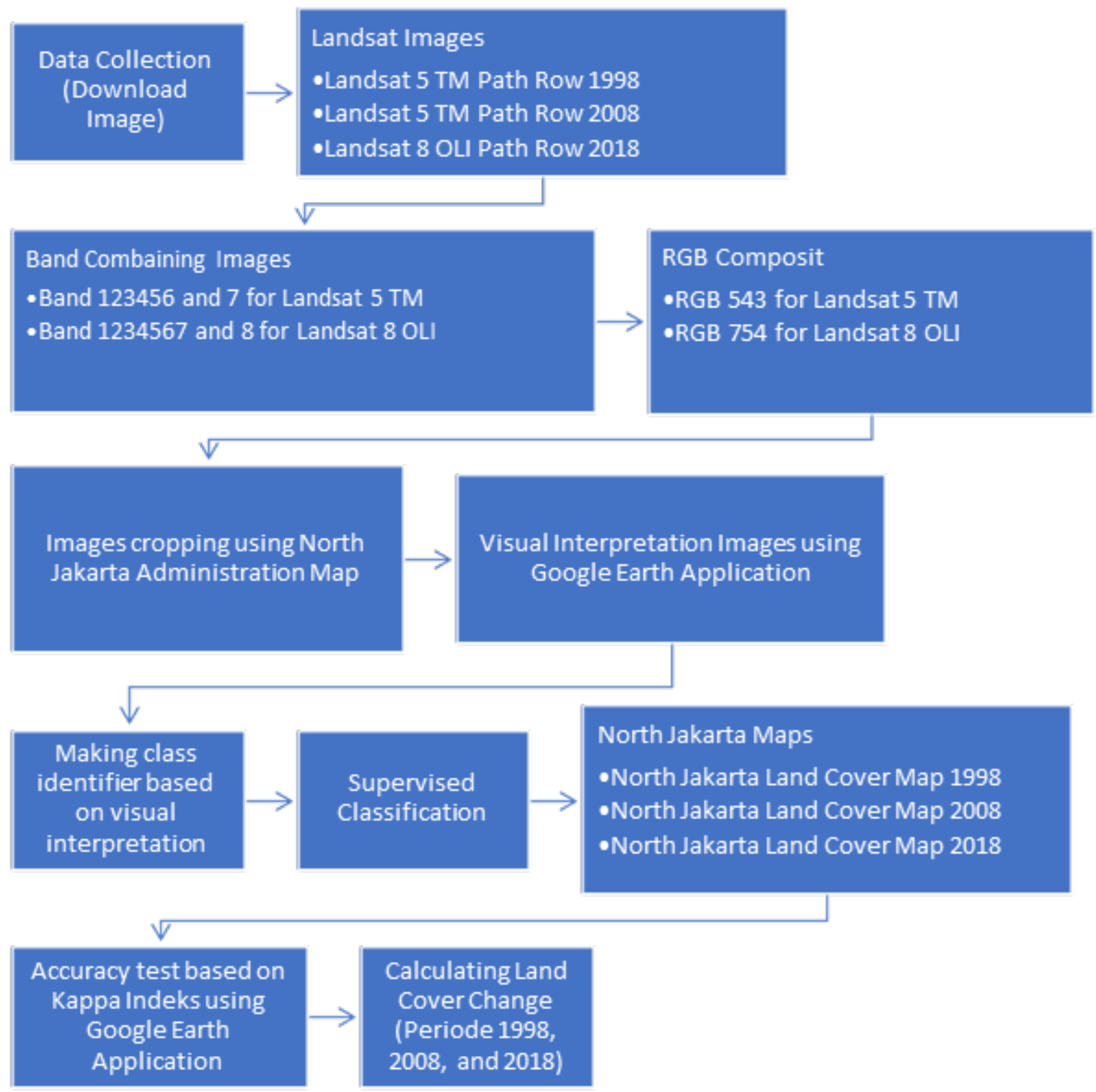

Figure 1. Land-use cover analysis flow chart.

class identifiers. Selection of the best band combination for land cover classification can be done through the evaluation of the Optimum Index Factor (OIF) (Jaya, 2010). The OIF value is a measure of the amount of information contained in a composite image. Based on study from Mentari (2013), the best band combination using OIF value for classify land cover using Landsat 8 images is the combination of band 754 where band 7 is SWIR-2 spectrum, band 5 is NIR spectrum, and band 4 is red spectrum.

Visual interpretation of images is carried out based on spatial recognition of object features. Characteristics of objects can be recognized based on elements of interpretation such as color, shape, size, pattern, texture, shadow, location and appearance associations. The interpreted image is displayed in RGB (Red Green Blue) format in the form of a composite image. We can compare the appearance on the image with the appearance on google earth application (Figure 2).

From the results of visual interpretation, the appearance of the Landsat $8 \mathrm{OLI}$ imagery with the reference from the google earth application in North Jakarta can be found several objects such as: mangroves, other vegetation (non-mangroves), ponds, water bodies, built-up land and open land.

Class identifiers are required in the classification process. A class identifier is a set of data obtained from a training area, feature space, or cluster. The training area or sample area is used to get class identifiers. A training area group represents one land cover class, for example forests, rice fields, water bodies, and built-up areas. According to Jaya (2010), theoretically the 

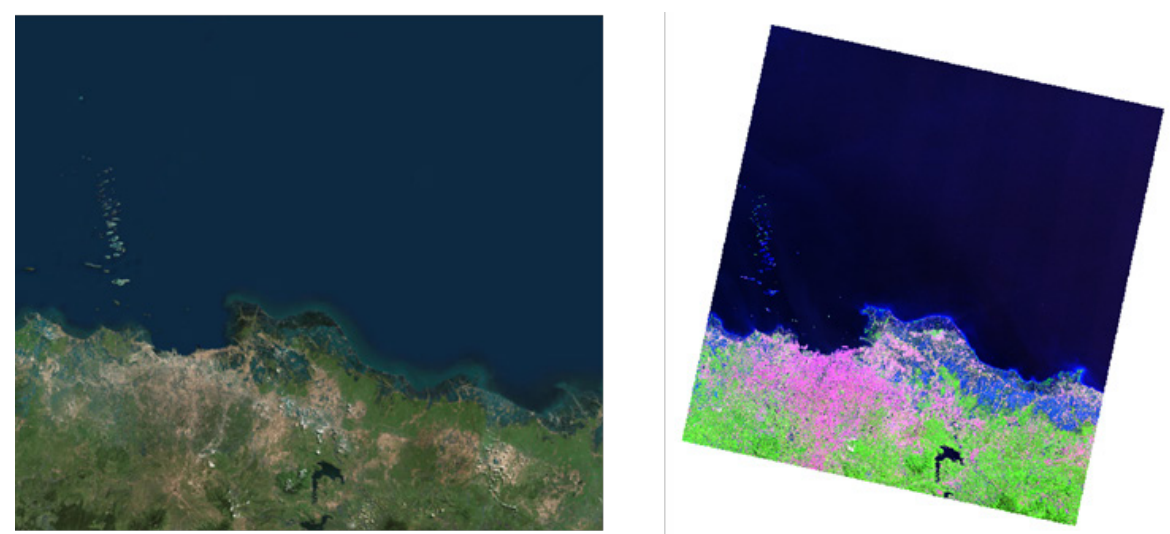

Figure 1. Landsat image display and Google Earth image.

number of pixels that must be taken per class is the number of bands used plus one $(\mathrm{N}+1)$. The training area is created using supporting data obtained from the Google Earth application to improve classification accuracy.

The image classification used in this study is a Supervised classification technique using the Maximum likelihood classification (MLC) method. MLC is the most commonly used method in remote sensing data classification (Foody et al., 1992; Jia et al., 2011). MLC also considers the probability factor of a pixel to be classified into a particular class or category. This opportunity is often called the prior probability, it can be calculated by calculating the percentage of cover on the image to be classified. If this probability is not known, then the magnitude of the probability is declared the same for all classes (one per number of classes created). This decision-making rule is called the Bayesian Decision Rule (Jaya, 2010).

The information resulted from the land cover classification of the North Coast of Jakarta from 1998 to 2018 must be presented in a communicative display based on the cartographic methods applied in the geography information system (GIS).

\section{RESULTS AND DISCUSSION}

\section{Overall accuracy}

Accuracy verification for the Jakarta coastline land cover in period 1998 to 2018 begins with determining the sample points to be compared with the appearance on Google Earth. The results of the comparison of the classification results with the appearance on Google Earth are presented using a contingency matrix (Table 2 ) with the following results.

Based on the overall calculation and the kappa index on the contingency matrix (Table 2), the results of the classification of land-use cover on the North Coast of Jakarta in the period 1998 to 2018 show an overall result of $90 \%$ and Kappa of 0.85 . Overall shows the percentage of the total sample tested, which is $90 \%$. This means that the results of the land cover classification can be accounted for, while the results of the kappa index calculation show the number 0.85 . According to the index made by the USGS, the classification results that can be used for information are those with a kappa index above 0.75. From the kappa index that the apprentices obtained, it means that the information from the results of the 1998-2018 land cover classification of the North Coast of Jakarta can be accounted for and utilized.

Table 2.

Contingency Matrix of Jakarta coastline land cover

\begin{tabular}{|c|c|c|c|c|c|c|c|}
\hline \multicolumn{3}{|l|}{ Sum of Value } & \multicolumn{3}{|c|}{ Land-use } & \multirow[b]{2}{*}{ Fishponds } & \multirow[b]{2}{*}{ Total } \\
\hline Land-use & Mangrove & $\begin{array}{l}\text { Developed } \\
\text { Land }\end{array}$ & $\begin{array}{l}\text { Other } \\
\text { Vegetations }\end{array}$ & $\begin{array}{l}\text { Water } \\
\text { Body }\end{array}$ & $\begin{array}{l}\text { Open } \\
\text { Land }\end{array}$ & & \\
\hline Mangrove & 7 & - & - & - & - & - & 7 \\
\hline Developed Land & - & 83 & 2 & 2 & 1 & 2 & 90 \\
\hline Other Vegetations & - & 1 & 39 & 1 & 1 & 2 & 44 \\
\hline Water Body & - & - & - & 1 & - & 3 & 4 \\
\hline Open Land & - & 1 & - & - & 24 & - & 25 \\
\hline Fishponds & 1 & - & - & 1 & - & 8 & 10 \\
\hline Total & 8 & 85 & 41 & 5 & 26 & 15 & 180 \\
\hline
\end{tabular}




\section{Landuse changes}

Land cover classification and Landsat image analysis from 1998 (Figure 3), 2008 (Figure 4), and 2018 (Figure 5) in North Jakarta. Based on the land cover classification and analysis in the period 1998 (Figure 3), 2008 (Figure 4), and 2018 (Figure 5), it shows that during the periods each land cover class experienced significant changes and the changes interrelated between one land cover class and others land cover classes. Moreover, any other additional land cover class resulted in suppression other land cover classes.

\section{Mangrove cover and others vegetation}

From the results of the analysis of land cover and the graph of the dynamics of land cover above, it shows that the area of mangrove land from 1998 (Figure 3) to 2008 (Figure 4) has decreased by 117 hectares. However, from 2008 to 2018 (Figure 5) there was an increase of 196 hectares. And if we look at the area dynamics from 1998 to 2018, this mangrove land cover class has increased by 79 hectares.

The area of other vegetation has also decreased in line with the decreasing area of mangrove areas in Jakarta, where from 1998 to 2008 there was a decrease in the area of 695 hectares. Although in 2008 to 2018 the area of vegetation land increased by 301 hectares, but from 1998 to 2018 in this other vegetation land cover class decreased by 393 hectares.

The increasing population in Jakarta ultimately have an impact on the increasing demand for the number of housing in the DKI Jakarta area. Along the Jakarta coast, massive development for residential and industrial areas has resulted in land used conversion

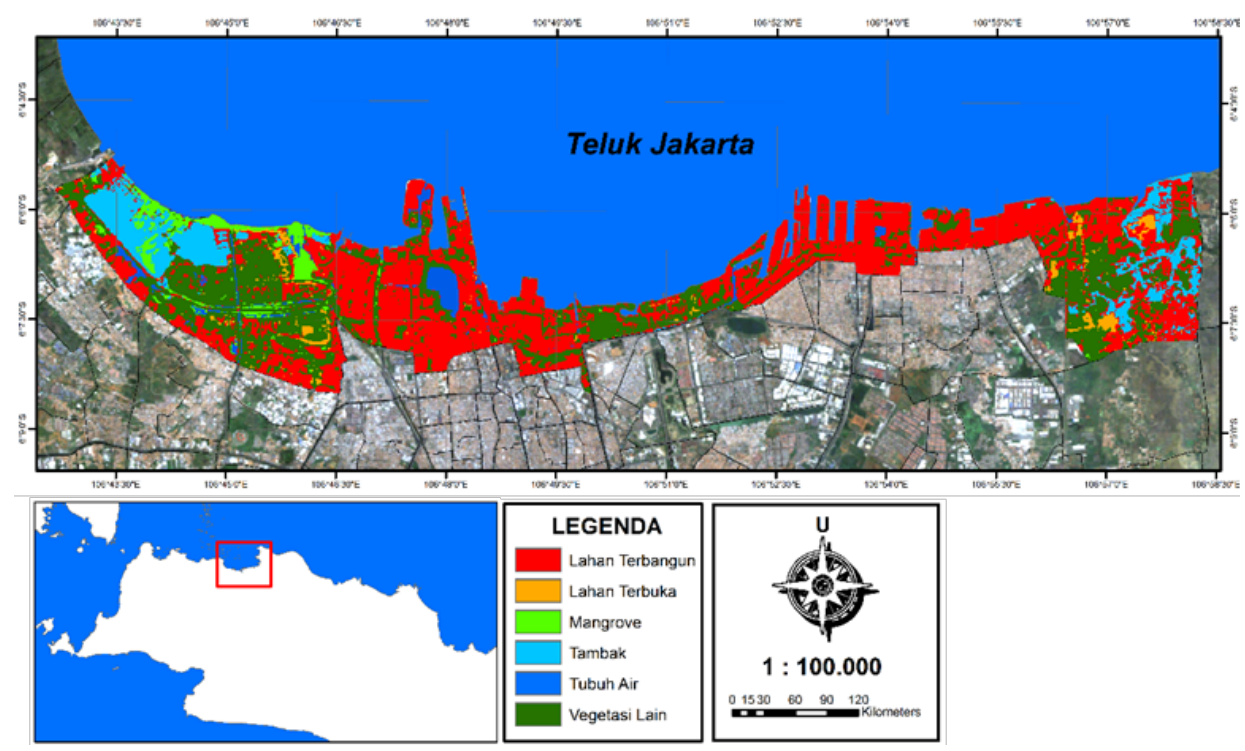

Figure 3. Land cover map in North Jakarta, 1998.

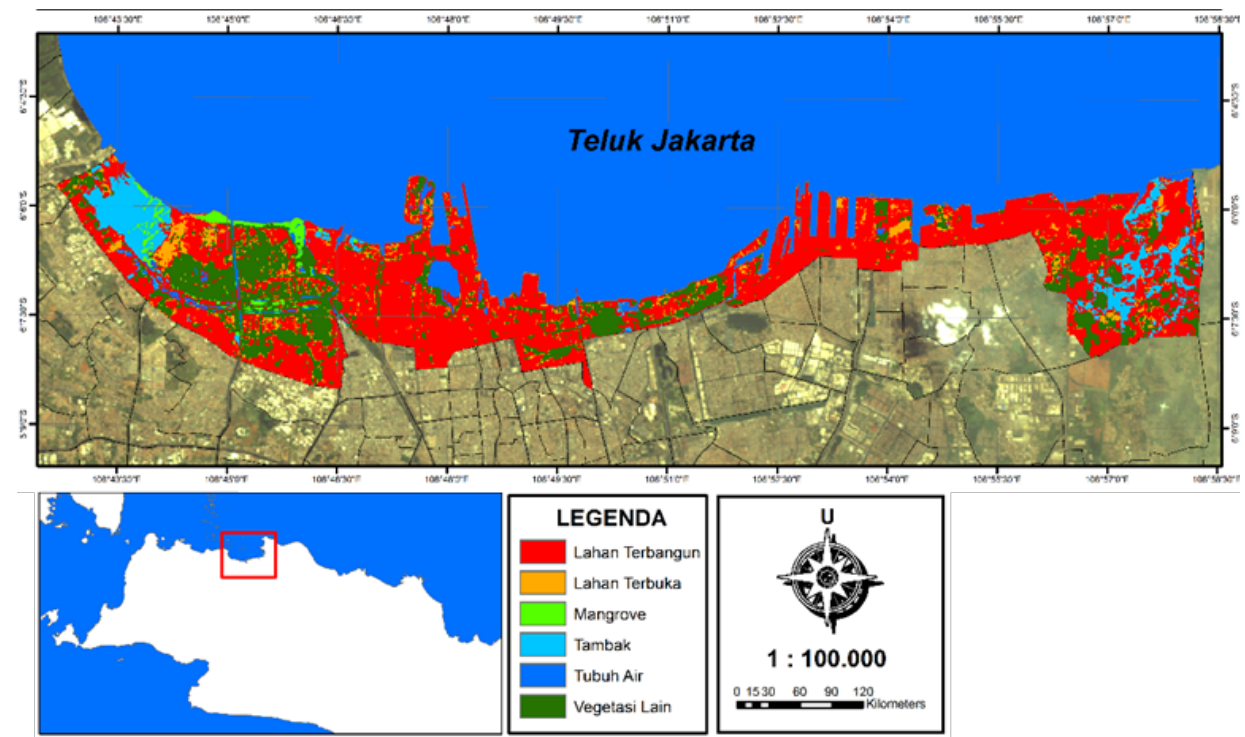

Figure 4. $\quad$ Land cover map in North Jakarta, 2008. 


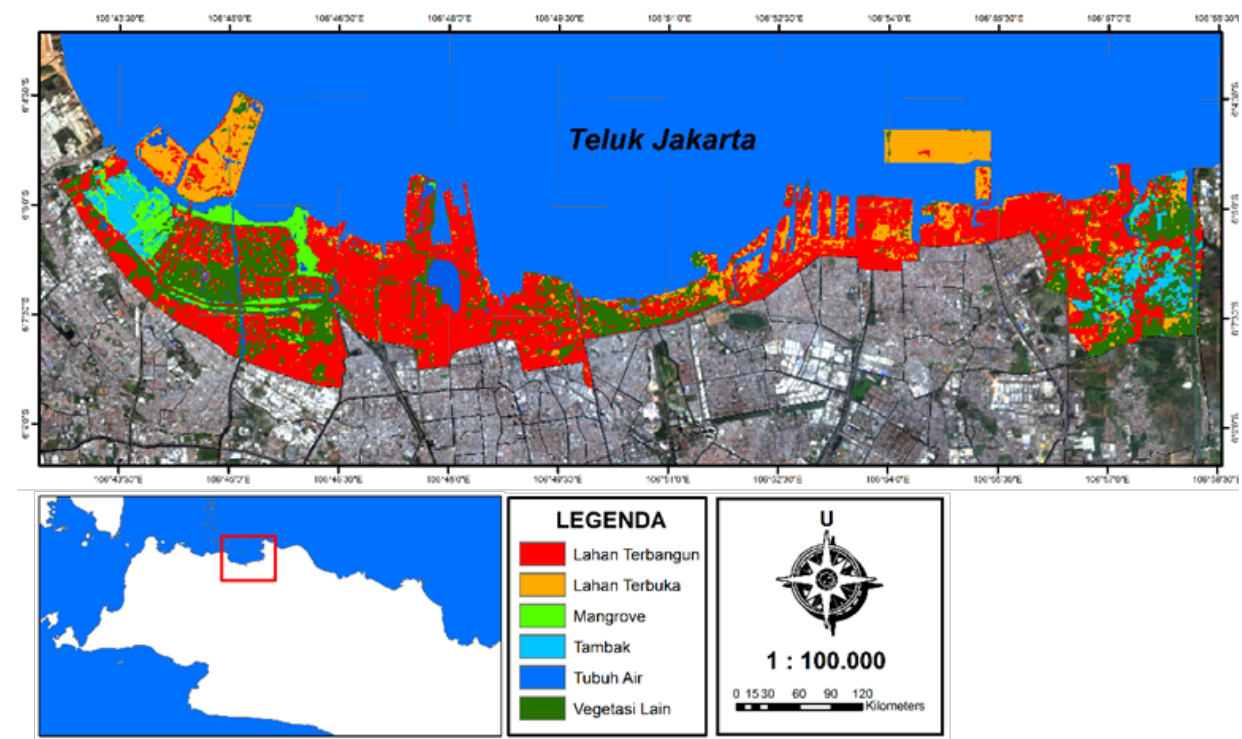

Figure 5. Land cover map in North Jakarta, 2018.

Table 2.

Contingency Matrix of Jakarta coastline land cover

\begin{tabular}{lllllll}
\hline Year & Mangrove & Built up land & $\begin{array}{l}\text { Other } \\
\text { vegetation }\end{array}$ & Water body & Open space & Ponds \\
\hline 1998 & 243.33 & 3214.6 & 2118 & 1020.7 & 150.11 & 651.65 \\
2008 & 126.54 & 3861.5 & 1422.5 & 951.03 & 412.2 & 488.52 \\
2018 & 322.38 & 3607 & 1724.3 & 224.19 & 1035.6 & 342.9 \\
\hline
\end{tabular}

and reclamation in Jakarta Bay. The conversion of land used in the coastal areas of Jakarta also resulted in a decrease in the number of mangrove areas, based on the references in 1960 the total area of mangroves in Jakarta reached about 1335 hectares. (Nur et al., 2001).

Mangrove ecosystems are very beneficial for humans and the environment, the existence of mangrove forests can prevent the intrusion of sea water to land and protect the coast from the threat of coastal abrasion. In addition, the existence of the mangrove ecosystem is very beneficial for marine animals which function as breeding or spawning areas for fish and other marine animals.

\section{Built up land cover and Open space}

From 1998 to 2018 there was an increase in the building area of 647 hectares. Although in 2008 to

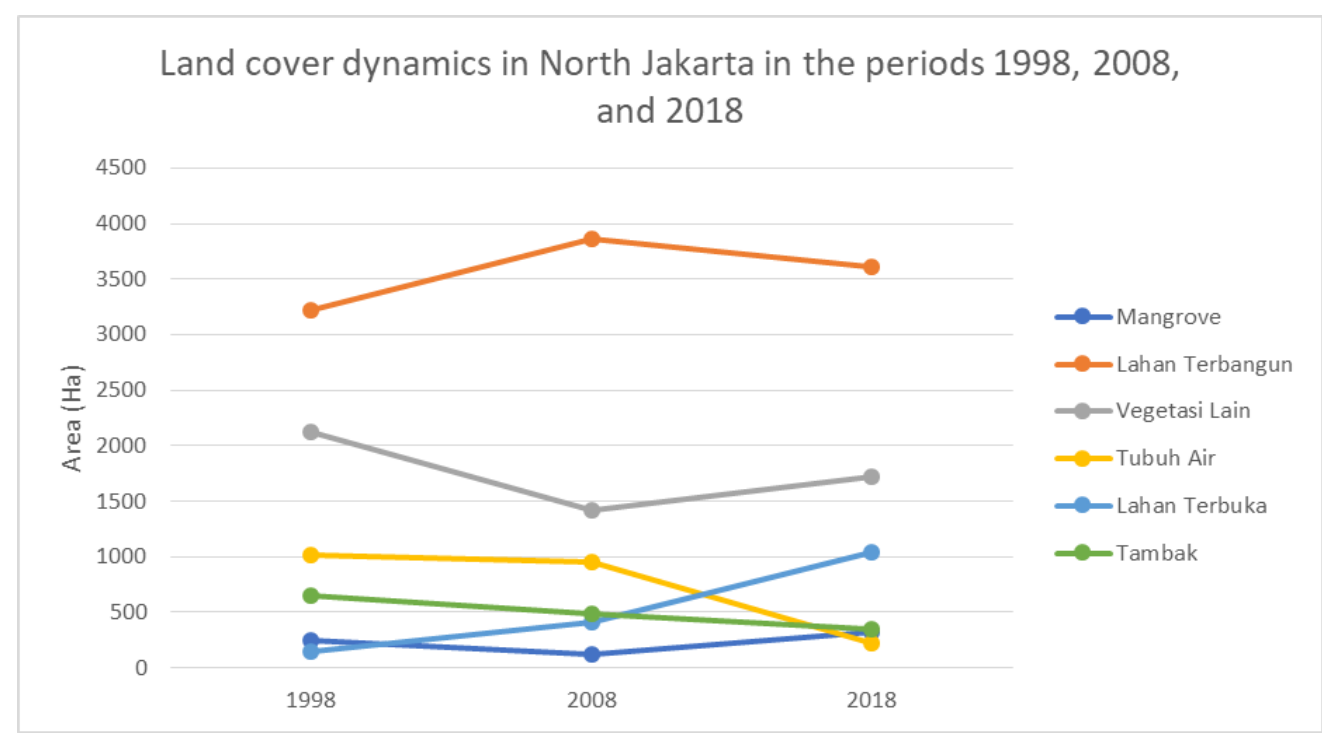

Figure 6. Land cover dynamics in North Jakarta in the periods 1998, 2008 and 2018. 
2018 it decreased by 255 hectares, overall the area dynamics from 1998 to 2018 in this building land cover class increased by 292 hectares. The same thing happened to the area of open land, where from 1998 to 2008 there was an increase in the area of 262 hectares and from 2008 to 2018 also experienced an increase of 625 hectares. Overall, the area from 1998 to 2018 in this open land cover class has increased by 887 hectares.

The increase in the area of land for buildings and the area of open land on the coast of Jakarta is a reaction from the government in its efforts to overcome the problems of residential and industrial land which are increasing in the Jakarta area. The DKI Jakarta Government in this case is carrying out reclamation in Jakarta Bay as an effort to gradually build new residential and industrial areas in the reclamation area. This can be seen from the changes in the land cover map from 1998 to 2018 as well as the total amount of built land which continues to increase year by year.

One result of the increase in building land and the high population in Jakarta is land subsidence. The rate of land subsidence along the coast of Jakarta is quite high. Research conducted by Chaussard et al. found that the rate of subsidence ranged from 9.5 to 21.5 $\mathrm{cm} /$ year during the 2007-2009 period (Chaussard et al., 2013). Another study conducted by Andreas on land subsidence in Jakarta found that the rate of subsidence varies from year to year. During the period 1925-1975 there was no significant land subsidence in Jakarta. Land subsidence has started since 1975 until now, and most of the subsidence has occurred in the North Jakarta area and areas close to the coastal areas (Andreas et al., 2016).

Research by Takagi et al. found that the main cause of land subsidence in Jakarta is partly due to the practice of extracting groundwater for industrial and household purposes. Land subsidence also increases the risk of flooding and inundation during heavy rains and monsoons. Jakarta experienced major floods in 1996, 2002, 2007, 2013 and 2014 (Takagi et al., 2016). In addition, due to climate change and rapid development, floods are predicted to occur more frequently in Jakarta's coastal areas. Although sea level rise and high tide are important factors in the risk of flooding, land subsidence is a major factor exacerbating the expansion of flood-affected areas in Jakarta (Takagi et al., 2016).

Based on research conducted by Takagi et al. show that the potential flood area in Jakarta will expand to $25.7 \mathrm{~km} 2$ in 2025 and $110.5 \mathrm{~km} 2$ in 2050 . Takagi et al. using a coastal hydrodynamic model and calculating sea level rise, land subsidence and high tide for flood projections in Jakarta. Meanwhile, research conducted by Andreas estimates that around $95.5 \%$ of the North Jakarta area will be inundated by 2050 (Andreas et al., 2016). Andreas uses the DEM model obtained from LiDar data, land subsidence rates from GPS and sea level rise rates from altimetry satellites.

\section{Ponds land cover and Water bodies}

The area of the ponds and water bodies on the North coast of Jakarta has continued to decline year by year. Based on the analysis, the area of ponds from 1998 to 2008 decreased by 164 hectares, while from 2008 to 2018 it also decreased by 145 hectares. Overall, from 1998 to 2018 area of ponds cover class has decreased by 309 hectares. The same results happened to the total area of water bodies, where from 1998 to 2008 there was a decrease of 70 hectares, and from 2008 to 2018 it also decreased by 727 hectares. Overall, the total area of the water bodies from 1998 to 2018 has decreased by 797 hectares.

Apart from the change in the function of ponds and water bodies on the North coast of Jakarta for reclamation and other development, the deteriorating environmental conditions have effect on the fishing profession. Currently, on the North coast of Jakarta many fishermen switching their professions and look for other jobs that are more profitable for their lives. Moreover, polluted material transported to Jakarta Bay via rivers flowing through Jakarta has affected the condition of marine species in Jakarta Bay.

Research conducted by Prihatiningsih et al. found that the milkfish species cultivated by fishermen in Jakarta Bay were contaminated by radionuclide materials $137 \mathrm{Cs}$. This pollutant probably derived from the disposal of the nuclear facility located in Tangerang Regency and was carried by the Cisadane River to Jakarta Bay. The author emphasizes conducting further research on the effect of ${ }^{137} \mathrm{Cs}$ on the marine ecosystem in Jakarta Bay.

Cultivation of green mussel (Perna Viridis) in Jakarta Bay provides economic income for coastal communities in Jakarta. The cultivation and processing of green mussels in Jakarta Bay absorbs around 10,000 workers with a total pond of 15,220 (BPS, 2017). Even with poor water quality, green clams can be cultivated in Jakarta Bay. However, research conducted by Huhn et al. found that the ability of stress tolerance between green clams in Jakarta Bay and green clams from other regions was different. The author explains that green mussels from Jakarta Bay perform better under hypoxic conditions, whereas other green mussels in less polluted areas perform better under hyposaline conditions (Huhn et al., 2016). 


\section{CONCLUSION}

Based on the results of the analysis of Landsat imagery in 1998, 2008 and 2018, there was a change in land use in the northern coastal area of Jakarta. In general, there has been a significant increase in the area of built land (buildings) and open land in the coastal areas of Jakarta, this occurred due to reclamation activities and new land clearing for new residential and industrial areas in the North Jakarta area.

Development in the Jakarta area has had a direct impact on decreasing the area of mangrove and other vegetation. The decline in the area of mangroves and other vegetation in the North Jakarta area has disrupted the mangrove ecosystem and other marine ecosystems that depend on the existence of mangrove forests. The damage to the mangrove ecosystem has resulted in a reduced function of mangroves as a place to spawn and breed fish, molluscs or bird species that depend on the existence of mangrove forests.

Reclamation and land use change also have an impact on decreasing the area of fish ponds and water bodies in Jakarta. This is exacerbated by declining water quality due to pollution in the Jakarta Bay area. Several studies have stated that the species cultivated in Jakarta Bay have been heavily contaminated with waste and have different levels of tolerance compared to species cultivated elsewhere.

\section{ACKOWLEDGEMENTS}

This research is funded by the Marine Research Centre, The Agency for Research and Human Resource, Ministry of Marine Affairs and Fisheries Republic of Indonesia. Both authors have equal contribution in preparing the manuscript.

\section{REFFERENCE}

AAndreas, H., Abidin, H.Z., \& Gumilar, I. (2016). Respond to the land subsidence sea level rise and tidal inundation in Jakarta, in: Forum Group Discussion National Capital Integrated Coastal Development. pp. 1-53.

BPS. (2017). Jakarta in Figures 2017. Statistics of DKI Jakarta Province, Jakarta.

Chaussard, E., Amelung, F., Abidin, H., \& Hong, S.H. (2013). Sinking cities in Indonesia: ALOS PALSAR detects rapid subsidence due to groundwater and gas extraction. Remote Sens. Environ, 128, 150161. https://doi.org/10.1016/j.rse.2012.10.015

Firman, T., Surbakti, I.M., Idroes, I.C., \& Simarmata, H.A. (2011). Potential climate-change related vulnerabilities in Jakarta: Challenges and current status. Habitat Int. 35, 372-378. https://doi. org/10.1016/j.habitatint.2010.11.011

Huhn, M., Hattich, G.S.I., Zamani, N.P., von Juterzenka, K., \& Lenz, M. (2016). Tolerance to stress differs between Asian green mussels Perna Viridis from the impacted Jakarta Bay and from natural habitats along the coast of West Java. Mar. Pollut. Bull, 110, 757-766. https://doi.org/10.1016/j. marpolbul.2016.02.020

Kusmana, C., Setiawan, Lestari, D.F., Meidilaga, Ardha, M.J., Wulandari, R.R., Permana, R., \& Yahdi, D. (2013). Fauna Mangrove Di Kawasan Hutan Angke Kapuk. Jakarta.

NCICD Consortium. (2015). National Capital Intergrated Coastal Development Master Plan. Jakarta.

Nur, Y., Fazi, S., Wirjoatmodjo, N., \& Han, Q. (2001). Towards wise coastal management practice in a tropical megacityFJakarta. Ocean Coast. Manag. 44, 335-353. https://doi.org/10.1016/S09645691(01)00054-0

Prihatiningsih, W.R., Suseno, H., Zamani, N.P., \& Soedharma, D. (2016). Bioaccumulation and retention kinetics of cesium in the Milkfish Chanos chanos from Jakarta Bay. Mar. Pollut. Bull, 110, 647-653. https://doi.org/10.1016/j. marpolbul.2016.04.058

Takagi, H., Esteban, M., Mikami, T., \& Fujii, D. (2016). Projection of coastal floods in 2050 Jakarta. Urban Clim. 17, 135-145. https://doi.org/10.1016/j. uclim.2016.05.003 
Land Use Changes Analysis ...... Between 1998, 2008 And 2018 (Rizal, A., \& Haykal, F. 